\title{
Go Then and Plant a Tree
}

\section{STUART FRANCIS, Torch River.}

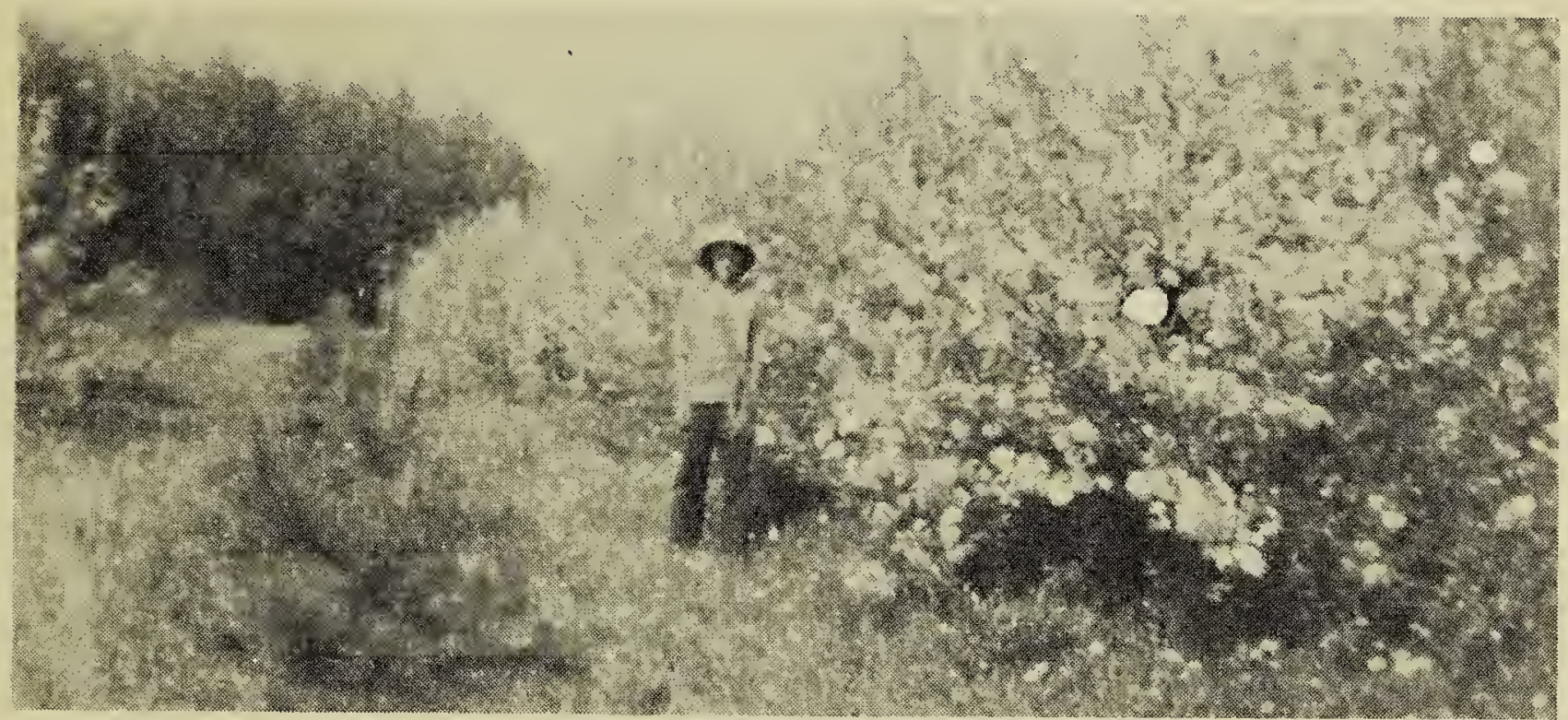

Apple-blossom time at Sprucedale Farm.

This has been a mild winter all the way through, with the exception of three or four cold days in January when the mercury dropped on one occasion to a low of forty-two degrees below zero. But for the most part it has been an easy winter for the native birds and animals.

The deers are to be noted with sleek coats and well covered bodies, as they have had lots of good feed found around threshing sets, sheaf stacks, etc. However, one large buck with a very fine set of antlers met a tragic fate over on our west place during December, by trying to cross several yards of ice which had seeped through a beaver dam. The way he was lying on the ice gave us the impression that he had slipped, and the legs had spread so far apart as to have paralyzed the spine, so that it had been unable to move at all. We came upon it when we observed an unusual number of fox, coyote, and an occasional Timber Wolf track, all leading to the spot where the tragedy had occurred.

Bohemian Waxwings and Evening Grosbeaks have been quite numerous all winter and have not had any difficulty finding a square meal, with lots of leaves and maple seeds to dine on.
The usual early and late daily parade of our barnyard friends, the Ruffed Grouse, has been carried on as usual, for the fourth winter now, while Sharptails are to be seen feeding at the pigs' trough every morning.

The boys trapped a coyote in late November and hung the very fat carcass up about seven feet off the ground. It has provided a continuous meal ticket for several Blackcapped Chickadees, a pair of Hudsonian Chickadees, Hairy Woodpeckers, Downy Woodpeckers, and Canada Jays. Sometimes as many as three species could be seen feeding, all at the same time, until now, all that is left is an almost bare skeleton.

Before the second-quarter of the "Blue Jay" appears, most of us will have been busy seeding and planting for this year's crops, so while we are at it, let all of us that live on a farm, with all its wides spaces and often unused fence cover or slough borders, do a bit of planting that will endure for many decades in the future. Plant a few trees, or quite a nice big lot of them, if you like, for there is nothing more attractive than a stately pine or spruce, or a spreading maple or elm or oak. So early in the spring do as the poet says, in the following lines, by Marion Couthouy Smith:

"Go, then, and plant a tree, lovely in sun and shadow, Gracious in every kind, maple and oak and pine Peace of the forest glade, wealth of the fruitful meadow, Blessing of dew and shade, hereafter shall be thine." 